Original Research Article

\title{
In vitro study on antioxidant activity of methanolic leaf extract of Cassia fistula Linn.
}

\author{
Bindhu R. Kamath, Sabeena Kizhedath*
}

Department of Pharmacology, Government Medical College, Ernakulam, Kerala, India

Received: 27 February 2018

Accepted: 23 March 2018

\section{*Correspondence to:}

Dr. Sabeena Kizhedath, Email: drsabeenakizhedath@ gmail.com

Copyright: (C) the author(s), publisher and licensee Medip Academy. This is an openaccess article distributed under the terms of the Creative Commons Attribution NonCommercial License, which permits unrestricted noncommercial use, distribution, and reproduction in any medium, provided the original work is properly cited.

\begin{abstract}
Background: The use of medicinal plants for maintaining good health is getting attention worldwide. Antioxidants play an important role to protect damage caused by oxidative stress. In the present study methanolic extracts of Cassia fistula was determined using DPPH for its antioxidant activity. Phytochemical investigation confirmed the presence of bioactive ingredients in the extract.

Methods: The antioxidant activity of methanolic extract of Cassia fistula was evaluated using DPPH free radical assay. DPPH (1,1-diphenyl-2picrylhydrazyine) free radical analysis is one of the accurate and frequently employed method for evaluating antioxidant activity.

Results: The methanolic extracts showed increase in radical scavenging activity as concentration increases. The IC50 values were calculated for the methanolic extract. Ascorbic acid was used as control. Cassia fistula exhibited IC50 of $79.42 \mu \mathrm{g} / \mathrm{ml}$.

Conclusions: Scientific evidence suggests that antioxidants reduce the risk for chronic diseases including cancer and heart disease and infectious diseases. Further evaluation of pharmacological activities of Cassia fistula may prove useful in treatment of cancer and heart diseases.
\end{abstract}

Keywords: Antioxidant activity, Cassia fistula, DPPH, IC50

\section{INTRODUCTION}

Over the last few years, researchers have aimed at identifying and validating plant-derived substances for the treatment of various diseases. Interestingly it is estimated that nearly $25 \%$ of the modern medicines are directly or indirectly derived from plants. It is worth mentioning that Indian medicinal plants are considered as a vast source of several pharmacological principles and compounds that are commonly used as home remedies against multiple ailments. ${ }^{1}$

With the emerging worldwide interest in adopting and studying traditional systems and exploiting their potential based on different health care systems, the evaluation of the rich heritage of traditional medicine is essential. ${ }^{1}$
Cassia fistula Linn. (leguminosae), Indian Laburnum (Golden shower tree) is a very common plant known for its medicinal properties. Antioxidant activity power was in the decreasing order of stem bark, leaves, flowers and pulp and was well correlated with the total polyphenolic content of the extracts. ${ }^{1}$

Aragvadha or Cassia fistula is one of the four hundrerd and odd species comprising the genus Cassia and is widely distributed all over. ${ }^{2}$ Extract of Cassia fistula showed anti inflammatory, hypoglycaemic, hepatoprotective, anti fertility and antioxidant activity. ${ }^{3}$ In the Indian literature this plant has been described to be useful against skin diseases, liver troubles, tuberculous glands. ${ }^{4}$ The lipid oxidation process is involved in oxidative damage at cellular level leading to ageing. ${ }^{5}$ Cassia fistula is widely 
used for its antitumor, hepatoprotective, antifertility, antioxidant properties as well as its actions on central nervous system, wound healing and inhibitory effect on leukotrine biosynthesis. ${ }^{6}$ There is overwhelming evidence showing that natural antioxidants play a role in wellness, health maintenance and prevention of chronic degenerative disease. ${ }^{7}$ Natural antioxidants can protect a human body from radicals and retard the process of many chronic diseases as well as lipid oxidative rancidity in foods. Hence the studies on natural antioxidants have greater importance. ${ }^{8}$

The plant has been reported to possess antioxidant properties as well as antimicrobial properties by different studies conducted in India as well as other countries. Plants growing in different climatic and seasonal conditions do not have identical constituents or therapeutic effects. ${ }^{9}$ Thus active components may differ in nature or concentration. Phytochemical analysis of the crude extracts can indicate the presence of active constituents in the plant.

Antioxidants that can trap free radicals are our crucial defence against free radical induced damages and are crucial for maintaining optimum health. They can reduce the risk for chronic diseases including cancer and heart disease. ${ }^{10}$

The search for plant derived antioxidants has been received much attention and effort in order to identify the compounds that have high capacity in scavenging free radicals related to various diseases. Generally, antioxidant compounds like Phenolic acids, poly phenols and flavonoids scavenge free radicals such as peroxide, hydroperoxide of lipid hydroxyl and thus inhibit the oxidative mechanism that lead to degenerative diseases. ${ }^{11}$

\section{METHODS}

\section{Collection of plant materials}

Fresh leaves of Cassia fistula were collected from GMC, Ernakulam campus in month of May- June. Leaves were shade dried and crushed into fine powder with electric blender. The powdered sample were sealed in polythene box and stored.

\section{Preparation of methanolic extracts: Sample preparation}

Preparation of methanol extract: Dried and powdered leaves $(25 \mathrm{~g})$ were used. The extract is prepared using Soxhlet apparatus. Powdered leaves with $200 \mathrm{ml}$ of methanol was subjected for extraction for about $10 \mathrm{~h}$ in a water bath. The crude plant extract in solvent was removed from the Soxhlet apparatus and concentrated to dryness in water bath and is stored in refrigerator.

\section{Phytochemical screening}

Preliminary phytochemical screening was performed by using standard tests.

\section{Test for alkaloids}

Dragendroff's test: $1 \mathrm{ml}$ of extract+ $1 \mathrm{ml}$ of mayers reagent. Yellow precipitate

Glycosides

$1 \mathrm{ml}$ of extract+ $1 \mathrm{ml}$ of water+ Aq. NaOH. Yellowish brown precipitate

\section{Flavanoids}

$1 \mathrm{ml}$ extract $+10 \%$ lead acetate. Yellowish green precipitate

\section{Saponins}

$1 \mathrm{ml}$ extract + boiled with $1 \mathrm{ml}$ of distilled water. Froth

Tannins

$1 \mathrm{ml}$ extract $+0.1 \% \mathrm{Fecl}_{3}$. Brownish green precipitate

\section{Terpenoids}

$1 \mathrm{ml}$ extract+ $1 \mathrm{ml}$ of $\mathrm{CHCl}_{3}+2 \mathrm{ml}$ conc. $\mathrm{H}_{2} \mathrm{SO}_{4}$. Brown precipitate

Proteins

$1 \mathrm{ml}$ extract $+1 \mathrm{ml} 40 \% \mathrm{NaOH}+2$ drps of $1 \% \mathrm{CuSO}_{4}$. Pink color

\section{Carbohydrates}

Benedicts test: $1 \mathrm{ml}$ extract $+5 \mathrm{ml}$ benedicts reagent. Boil 2 minutes and cool. Slight red precipitate

\section{DPPH radical scavenging activity}

DPPH free radical scavenging of Cassia fistula methanolic extracts was estimated according to the method of Blois et al. ${ }^{12}$ Free radical scavenging ability of the extracts was tested using DPPH radical scavenging assay. Stock solution of the whole plant extract was prepared to concentration of $1 \mathrm{mg} / \mathrm{ml}$. A solution of $0.1 \mathrm{mM}$ DPPH was prepared. To $1 \mathrm{ml}$ this solution $3 \mathrm{ml}$. of different concentration extracts in methanol were added. The mixture was shaken vigorously and allowed to stand at room temperature for $30 \mathrm{~min}$. Then, absorbance was measured at $517 \mathrm{~m}$. by using spectrophotometer. Ascorbic acid was used as reference standard. Lower absorbance of the reaction mixture indicates higher free radical activity. All the tests were performed in triplicate.

The percent DPPH scavenging effect was calculated by using following equation:

DPPH scavenging effect $(\%)$ or Percent inhibition $=\mathrm{A} 0-$ A $1 /$ A $0 \times 100$. 
Where A0 was the Absorbance of control reaction and A1 was the Absorbance in presence of extracts/standard

The $\%$ of inhibition was plotted against concentration, and from the graph IC50 was calculated.

Values are the average of triplicate experiments and are represented as mean $(n=3)$.

\section{Statistical analysis}

Results are expressed as mean value $(n=3)$. Regression analysis was performed to calculate the dose response relationship of the extract.

\section{RESULTS}

The radical scavenging activity of methanolic leaf extracts was be determined on the basis of the radical scavenging effect on the DPPH (2, 2-diphenyl-1- picrylhydrazyl). DPPH is a stable free radical and accepts hydrogen radical to become diamagnetic molecule. The solution appears a deep violet colour and changes to yellow after accepting hydrogen. The reduction capability of DPPH radical was determined by decrease in its absorbance at $517 \mathrm{~nm}$ which is induced by antioxidants. The decrease in absorbance of DPPH radical caused by antioxidants because of the reaction between antioxidant molecules and DPPH which results in the scavenging of the radical by hydrogen donation. It is visually noticeable as a change in colour from purple to yellow. Cassia fistula methanolic extracts exhibited a comparable antioxidant activity with that of standard ascorbic acid at varying concentrations tested. There was a dose dependent increase in the percentage antioxidant activity for all concentrations tested. All the tests were done in triplicate and the values were plotted as mean $=$ standard deviation. The IC50 values of methanolic leaf extract of Cassia fistula by DPPH method is obtained as $79.42 \mu \mathrm{g} / \mathrm{L}$.

Table 1: Phytochemical screening of methanolic extract of Cassia fistula leaf.

\begin{tabular}{|ll|}
\hline $\begin{array}{l}\text { Phytochemical } \\
\text { constituent }\end{array}$ & $\begin{array}{l}\text { Methanolic extract } \\
\text { Cassia fistula }\end{array}$ \\
\hline Alkaloids & + \\
\hline Glycosides & + \\
\hline Flavanoids & + \\
\hline Saponins & + \\
\hline Tannins & + \\
\hline Terpenoids & + \\
\hline Proteins & + \\
\hline Carbohydrates & + \\
\hline
\end{tabular}

Phytochemical composition of plant extract

(+) Indicate Present and (-) Indicate Absent

Table 1 represents phytochemical screening of Cassia fistula leaf extract. It shows presence of alkaloids, glycosides, flavoniods, saponins, tannins, terpenoids, proteins and carbohydrates.

Table 2 Shows percentage inhibition of methanolic leaf extract of Cassia fistula at concentrations $(\mu \mathrm{g} / \mathrm{ml})$ in DPPH scavenging model.

Table 2: Percentage inhibition of methanolic leaf extract of Cassia fistula at concentrations $(\mu \mathrm{g} / \mathrm{ml})$ in DPPH scavenging model.

\begin{tabular}{|ll|}
\hline Concentration $(\mu \mathrm{g} / \mathrm{ml})$ & \% Inhibition \\
\hline 8.6 & 3.99 \\
\hline 17.2 & 8.92 \\
\hline 25.8 & 15.22 \\
\hline
\end{tabular}

Values are mean of three measurements

Increasing the concentration of Cassia fistula $(8.6 \mu \mathrm{g}$, $17.2 \mu \mathrm{g}, 25.8 \mu \mathrm{g})$ shows a linear increase in its antioxidant activity. The mean value $(n=3)$ of antioxidant activity at each concentration is $3.99,8.92$ and 15.72 respectively.

Table 3: Percentage inhibition of standard Ascorbic Acid at concentrations $(\mu \mathrm{g} / \mathrm{ml})$ in DPPH scavenging model Concentration.

\begin{tabular}{|lc|}
\hline Concentration $(\mu \mathrm{g} / \mathrm{ml})$ & \% Inhibition \\
\hline 0.143 & 0.82 \\
\hline 0.28 & 16.69 \\
\hline 0.42 & 27.34 \\
\hline 0.56 & 40.57 \\
\hline
\end{tabular}

Values are mean of three measurements

Increasing the concentration of standard Ascorbic acid $(0.143 \mu \mathrm{g}, 0.28 \mu \mathrm{g}, 0.42 \mu \mathrm{g}$ and $0.56 \mu \mathrm{g})$ shows a linear increase in its antioxidant activity. The mean value $(n=3)$ of antioxidant activity at each concentration is $0.82,16.69$, 27.34 and 40.57 respectively

Table 4 shows IC50 values of Ascorbic acid which is $0.67 \mu \mathrm{g} / \mathrm{ml}$ and the sample methanolic extract of Cassia fistula leaf which is $79.4 \mu \mathrm{g} / \mathrm{ml}$. IC50 represent a concentration that will scavenge $50 \%$ of the free radicals.

Table 4: IC50 Values of ascorbic acid and methanolic extract of Cassia fistuala Linn leaf.

\begin{tabular}{|ll|}
\hline Specification & IC 50 \\
\hline Ascorbic acid & $0.67 \mu \mathrm{g} / \mathrm{ml}$ \\
\hline $\begin{array}{l}\text { Methanolic extract of Cassia fistuala } \\
\text { Linn leaf }\end{array}$ & $79.42 \mu \mathrm{g} / \mathrm{ml}$ \\
\hline
\end{tabular}

A straight line graph is obtained by plotting between different concentration and $\%$ inhibition. $\mathrm{R}^{2}$ is the regression coefficient.

Ascorbic acid is a proven antioxidant, which is used as a standard in Antioxidant assays. Cassia fistula shows good antioxidant activity with an IC50 value of $79.4 \mu \mathrm{g} / \mathrm{ml}$. 


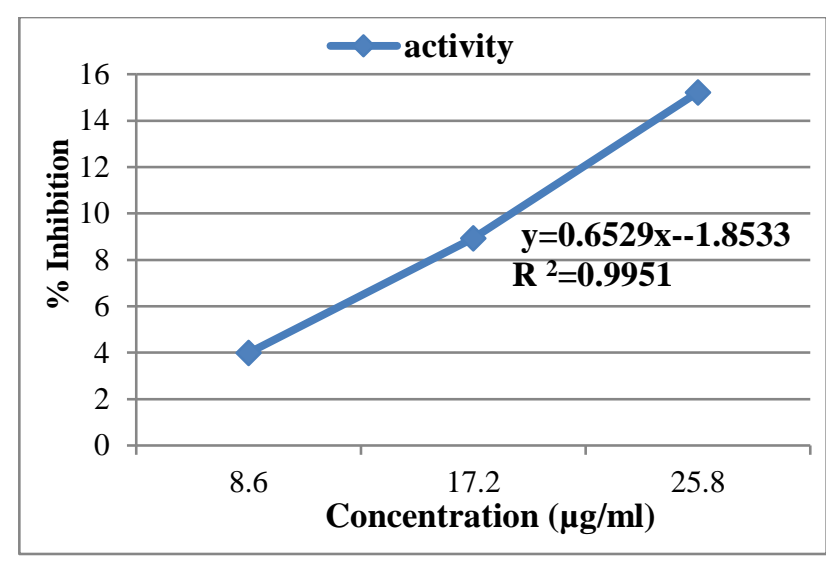

Figure 1: DPPH free radical scavenging activity of methanolic leaf extract of Cassia fistula.

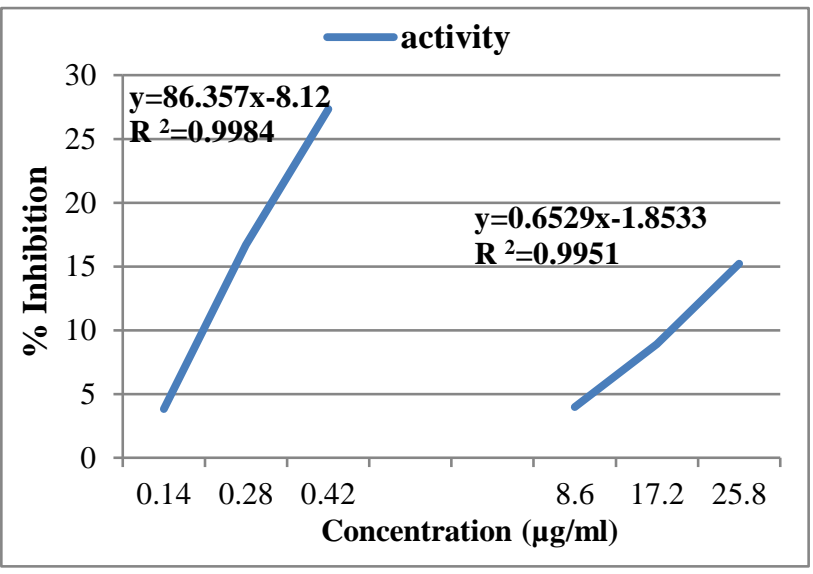

Figure 2: DPPH free radical scavenging activity of Std ascorbic acid and methanolic leaf extract.

\section{DISCUSSION}

DPPH analysis is the best known accurate and frequently employed methods for evaluating antioxidant activity. ${ }^{13}$ In this present study Cassia fistula methanolic leaf extract demonstrated significant antioxidant activity. This study is comparable to the study conducted by Md. Irshad et al, which showed significant antioxidant potential of various extracts Cassia fistula determined by DPPH, FRAP, $\mathrm{Fe}_{3+}$ reducing power and hydrogen peroxide scavenging assay. ${ }^{14}$ Bhalodia et al, recently reported the antioxidant activity of Cassia fistula flower in DPPH assays. ${ }^{15}$

Antioxidants are the compounds that neutralise the attack of free radicals and therefore reduce the risk of disorders. ${ }^{16}$ Abid $\mathrm{R}$ et al, in his study demonstrarted antioxidant and protective effect of Cassia fistula Linn fruit extracts. ${ }^{17} \mathrm{~A}$ study was performed by Lia TK et al, which showed Cassia fistula bark extracts have high antioxidant activity. ${ }^{18}$ In another study done by Evans $\mathrm{R}$ et al, to investigate the antioxidant activities of Cassia fistula with $90 \%$ ethanol extracts of leaves and $90 \%$ methanol extracts of stem bark. ${ }^{19}$ In a study done by Siddhuraju et al, the stem bark of Cassia fistula demonstrated high antioxidant activity. ${ }^{20}$ Pulp and flowers results confirmed that stem bark showed high antioxidant activity. ${ }^{20}$ Teeshan Bahuron et al, revealed significant antioxidant from the aqueous extracts of Cassia fistula linn. ${ }^{4}$

Manomani et al, evaluated the antioxidant effect of aqueous extract of fistula (Linn.) flowers and results revealed the reversal back of antioxidant enzymes to near normal levels. ${ }^{21}$

\section{CONCLUSION}

From this study it is clear that crude extracts of Cassia fistula leaf contain medicinal active components. The preliminary Phytochemical investigation confirms the presence of bioactive components in the extract. The result of this study on Cassia fistula methanolic extract demonstrates significant antioxidant activity of Cassia fistula which can be used as easily accessible source of natural antioxidant. However, the components responsible for the antioxidant activity of methanolic extract are currently unclear. Therefore, further works have to be performed on the isolation and identification of the antioxidant compounds present in the plant extract.

Funding: Funding sources from SBMR, Kerala

Conflict of interest: None declared

Ethical approval: The study was approved by the Institutional Ethics Committee

\section{REFERENCES}

1. Danish M, Singh P, Mishra G, Srivastava S, Jha KK, Khosa RL. Cassia fistula Linn. (Amulthus)-An important medicinal plant: A review of its traditional uses, phytochemistry and pharmacological properties. J Nat Prod Plant Resour. 2011;1(1):101-18.

2. Iyengar MA, Pendse GS, Narayana N. Bioassay of Cassia fistula. L.(aragvadha). Planta medica. 1966 Aug;14(03):289-301.

3. Rizvi MM, El Hassadi IM, Younis SB. Bioefficacies of Cassia fistula: an Indian labrum. African journal of Pharmacy and Pharmacology. 2009 Jun 30;3(6):28792.

4. Bahorun T, Neergheen VS, Aruoma OI. Phytochemical constituents of Cassia fistula. African journal of Biotechnology. 2005;4(13).

5. Lee CK, Lee PH, Kuo YH. The chemical constituents from the aril of Cassia fistula L. Journal of the Chinese Chemical Society. 2001 Dec 1;48(6A):1053-8.

6. Kannampalli P, Chandrasekaran VRM, Kuppannan G. Protective effect of Cassia fistula Linn. On diethyl nitrosamine induced hepatocellular damage and oxidative stress ethanol pretreated rats. Biol Res. 2010;43:113-25.

7. Saraswathy A, Devi SN, Ramasamy D. Antioxidant, heavy metals and elemental analysis of Holoptelea integrifolia Planch. Indian journal of pharmaceutical sciences. 2008 Sep;70(5):683. 
8. Gülçin I, Mshvildadze V, Gepdiremen A, Elias R. Screening of antiradical and antioxidant activity of monodesmosides and crude extract from Leontice smirnowii tuber. Phytomedicine. 2006 May 9;13(5):343-51.

9. Bhalerao SA, Kelkar TS. Traditional medicinal uses, phytochemical profile and pharmacological activities of Cassia fistula Linn. International Research Journal of Biological Sciences. 2012 Sep;1(5):79-84.

10. Rajagopal PL, Premaletha K, Kiron SS, Sreejith KR. Phytochemical and pharmacological review on Cassia fistula Linn. The golden shower. International Journal of Pharmaceutical, Chemical \& Biological Sciences. 2013 Jul 1;3(3).

11. Subramaniaom LJ, Zakaria Z, Sreenivasan S. Phytochemical screening, DPPH free radical scavenging and xanthine oxidase inhibitory activities of Cassia fsitula seeds extract. Journal of Medicinal Plants Research. 2011;5(10):1941-7.

12. Blois MS. Antioxidant determinations by the use of a stable free radical. Nature. 1958 Apr;181(4617):1199.

13. Mathangi T, Prabhakaran P. DPPH Free Radical scavenging activity of the extracts of Aquatic fern Marsiekla Quadirifola Linn. Intetnational Journal of Current Microbiology and Applied Sciences. 2013;2(10):534-6.

14. Irshad M, Zafaryab M, Singh M, Rizvi M. Comparative analysis of the antioxidant activity of Cassia fistula extracts. International journal of medicinal chemistry. 2012;2012. Article ID 157125

15. Bhalodia NR, Nariya PB, Acharya RN, Shukla VJ. Evaluation of in vitro antioxidant activity of flowers of Cassia fistula Linn. International Journal of Pharm Tech Research. 2011 Jan;3(1):589-99.
16. Zhou K, Yu L. Effects of extraction solvent on wheat bran antioxidant activity estimation. LWT-Food Science and Technology. 2004 Nov 1;37(7):717-21.

17. Abid RI, Mahmood RI, Rajesh KP, Kumara Swamy BE. Potential in vitro antioxidant and protective effect of Cassia fistula Linn. fruit extracts against induced oxidative damage in human erythrocytes. Int J Pharm Pharm Sci. 2014;6:497-505.

18. Tzekiat L, Chiang LK. Total Phenolics, Total Tannins and Antioxidant Activity of Cassia fistula L. extracts of bark, stem, leaf and root under different age classes. Asian Journal of Pharmaceutical Research and Health Care. 2013;5(2).

19. Rice-Evans CA, Miller NJ, Paganga G. Structureantioxidant activity relationships of flavonoids and phenolic acids. Free radical biology and medicine. 1996 Jan 1;20(7):933-56.

20. Siddhuraju P, Mohan PS, Becker K. Studies on the antioxidant activity of Indian Laburnum (Cassia fistula L.): a preliminary assessment of crude extracts from stem bark, leaves, flowers and fruit pulp. Food chemistry. 2002 Oct 1;79(1):61-7.

21. Manonmani G, Bhavapriya V, Kalpana S, Govindasamy S, Apparanantham T. Antioxidant activity of Cassia fistula (Linn.) flowers in alloxan induced diabetic rats. Journal of Ethnopharmacology. 2005 Feb 10;97(1):39-42.

Cite this article as: Kamath BR, Kizhedath S. In vitro study on antioxidant activity of methanolic leaf extract of Cassia fistula Linn. Int J Basic Clin Pharmacol 2018;7:849-53. 